\title{
Do market prices correspond with consumer demands? Combining market valuation and consumer utility for extra virgin olive oil quality attributes in a traditional producing country
}

\author{
Petjon Ballco ${ }^{\mathrm{a}, \mathrm{b}, *}$, Azucena Gracia ${ }^{\mathrm{a}, \mathrm{b}}$ \\ ${ }^{a}$ Unidad de Economía Agroalimentaria y de los Recursos Naturales, Centro de Investigación y Tecnología Agroalimentaria de Aragón (CITA), Avda. Montañana 930, 50059, Zaragoza, Spain \\ ${ }^{\mathrm{b}}$ Instituto Agroalimentario de Aragón-IA2 (CITA-Universidad de Zaragoza), Zaragoza, Spain
}

\section{A R T I C L E I N F O}

\section{Keywords}

Extra virgin olive oil

Real choice experiment

Hedonic price

Consumer

\begin{abstract}
A B S T R A C T
The objective of this research is to examine whether there is a relationship between the value of attributes based on the market price and on consumer utilities. To address this objective, the results from a hedonic price (HP) approach are combined with the actual consumer utilities from a real choice experiment (RCE) for extra virgin olive oil (EVOO) attributes. The results indicate that the origin of production attribute positively influences consumer utility and it is also positively related to market EVOO prices. Conversely, the PDO quality certification positively influences consumer utility and willingness to pay, although it is not related to EVOO prices in the real market.
\end{abstract}

\section{Introduction}

At the beginning of the 21st century, the law of demand in food production supplanted the law of supply. Agricultural organisations and the agri-food industry must adapt to consumers' highly diversified expectations. In addition, consumers expect to be fully informed about the products they purchase. They demand healthy products that taste good and take into consideration social, ethical and environmental issues in terms of production practices and traditional production methods (Duquesne et al., 2006). Under this framework, the agro-food sector must continually seek strategic orientations to differentiate products, not only in the sense of increasing production but rather towards diversifying food supply by promoting attributes that are valued by consumers. Olive oil is an example of a product where greater differentiation has been associated with increased production and consumption worldwide.

Spain is by far the largest olive oil producer in the world, accounting for $40 \%$ of worldwide production, of which $80 \%$ is concentrated in southern Spain (MECS - Ministry of Education, Culture and Sports, 2017). Traditionally, olive oil consumption has been associated with gastronomic customs, being an essential ingredient in the Mediterranean diet (Dios-Palomares and Martínez-Paz, 2011; Sayadi et al., 2016). Consequently, consumption that was traditionally restricted to the Mediterranean area (mainly in Spain, Greece, and Italy who produce $68 \%$ and consume $45 \%$ ) is currently increasing in non-producing countries or emerging markets (especially USA, Canada, Australia, China, Japan, Argentina, Brazil, Chile, and Mexico) (Karanikolas et al., 2018; Roselli et al., 2016; Sayadi et al., 2016). The increase in consumption through these emerging markets is also reflected in the significant changes observed in the structure of world consumption and exports of olive oil (IOC - International Olive Council, 2019). More precisely, the average export in the last five seasons (from 2013 to 2014 to $2017-2018$ ) was 846,100 tonnes (t), which is $17.4 \%$ higher than in the previous five years $(720,600 t)$, and $35.6 \%$ more than in the previous two quinquennials $(623,800 t)$ (García-Galán et al., 2019).

One of the reasons for the increasing demand for olive oil is linked to increasing consumer awareness of the health benefits provided by the Mediterranean diet, in which olive oil is the main source of dietary fat (Salas-Salvadó et al., 2018). Medical research has revealed that regular olive oil consumption is significantly associated with lowered blood pressure and cholesterol (Storniolo et al., 2017), reducing the risk of certain cancers (Reboredo-Rodríguez et al., 2018), preventing cardiovascular disease (Salas-Salvadó et al., 2018), and assisting calcium absorption (Clodoveo et al., 2014; Xiong et al., 2014). Yet, besides the health benefits, preferences between consumers from the traditionally producing countries and those from the emerging markets have significantly changed. While in non-producing countries the con-

\footnotetext{
Abbreviations: EVOO, extra virgin olive oil; PDO, protected designation of origin; RCE, real choice experiment; HP, hedonic price; WTP, willingness to pay. * Corresponding author. Unidad de Economía Agroalimentaria y de los Recursos Naturales, CITA, Avda. Montañana 930, 50059, Zaragoza, Spain.

E-mail addresses: pballco@cita-aragon.es (P.); agracia@cita-aragon.es (A.)
} 
sumption of olive oil has increased enormously from low levels, Mediterranean countries, where consumption was relatively high, are now facing a shift towards the consumption of higher quality olive oils and, more specifically, extra virgin olive oils (EVOOs).

Regardless of the dynamism that EVOOs have been experiencing in the Spanish market, to the best of our knowledge, there is limited research that analyzes the extrinsic quality of EVOOs in Spain to provide knowledge about the price and the attributes that affect prices. More precisely, only Cabrera et al. (2015) examine the price structure for EVOO in Spain. Therefore, we address this gap by estimating recent market values for a high range of EVOO retail prices in the Spanish market by using a hedonic price (HP) approach. In Spain, use of the hedonic price approach in the food sector has been limited to studies by Ballco and de-Magistris (2018) on yogurts with nutritional and health claims, Sanjuán-López et al. (2009) on saffron, Gracia and Perez y Perez (2004) and Loureiro and McCluskey (2000) on veal, and Sánchez et al. (2000) on red wine.

Given the above, the objective of this research is to examine whether there is a relationship between the value of attributes based on price based on consumer utility. To respond to this objective, the results of the market valuation from an HP approach are combined with the actual consumer utilities from a real choice experiment (RCE). It is demonstrated in the literature that the HP method is an appropriate tool to determine the value of different EVOO attributes (Romo-Muñoz et al., 2015). The estimation of an HP function has the advantage of working with real products that are available to consumers in the marketplace and to estimate the value placed on each EVOO attribute and which of them contribute to the differentiation process (Cabrera et al., 2015). Although the price is not always the most important attribute to affect choices, it plays an important role in the exchange relationship between the retailer and the consumer and it is one of the most determinant variables in the decision to purchase the product (Angulo et al., 2000; González and Melo, 2008). Therefore, knowledge about price and the value of attributes will guide company pricing policy efforts and directly affect product demand. Hence, we first analyze the value placed on each EVOO attribute based on its price in the marketplace (Zaragoza-Spain) using an HP approach and then increase complexity by analyzing the value of the EVOO attributes based on consumer utility from the same marketplace through an RCE. Since we analyze the values of EVOO attributes at a local level (marketplace and consumers in Zaragoza-Spain), we expect to find a relationship between the highest valued EVOO attribute-based price and the highest valued EVOO attributes based on consumer utility. In particular, the main interest of the paper is assessing the ability of production origin (county, region, Spain) and its guarantee through the protected designation of origin (PDO) certification, as differentiation tools.

To the best of our knowledge, this is the first research that combines an HP approach with RCE to examine whether there is a relationship between the attribute valuation using market prices and the actual consumer utility for EVOO quality attributes. The outcomes from the combination of these two approaches are expected to improve knowledge about the value of EVOO quality attributes and to support producers in the development of new products and in the communication of those characteristics that matter the most to consumers.

\subsection{Background: consumer preferences for olive oil quality attributes}

Previous research exploring the consumption behavior for olive oil suggested that preferences differ not only between countries but also between regions. Table 1 contains a review of previous studies within the last 5 years, exploring consumer preferences for olive oil quality attributes and their key findings. The results of these studies are mixed regarding the degree of importance attached to specific attributes.
Table 1

Previous research (within the last 5 years), exploring consumer preferences for olive oil quality attributes and their key findings.

\begin{tabular}{|c|c|c|c|c|}
\hline Reference & Product & Country & $\begin{array}{l}\text { Analytical } \\
\text { method }\end{array}$ & Key findings \\
\hline $\begin{array}{l}\text { Panico et } \\
\text { al. (2014) }\end{array}$ & EVOO & Italy & $\begin{array}{l}\text { Discrete } \\
\text { choice } \\
\text { experiment }\end{array}$ & $\begin{array}{l}\text { The results showed that } \\
\text { information on origin, PDO } \\
\text { and PGI certification, } \\
\text { organic certification, } \\
\text { production method and } \\
\text { organoleptic characteristics } \\
\text { crucially affect consumer } \\
\text { preferences for olive oil. }\end{array}$ \\
\hline $\begin{array}{l}\text { Vázquez- } \\
\text { Araújo et } \\
\text { al. (2014) }\end{array}$ & $\begin{array}{l}\text { Olive } \\
\text { oil }\end{array}$ & $\begin{array}{l}\text { Spain } \\
\text { USA }\end{array}$ & $\begin{array}{l}\text { Preference } \\
\text { mapping }\end{array}$ & $\begin{array}{l}\text { The Spanish and the } \\
\text { imported USA EVOOs were } \\
\text { characterized by having } \\
\text { bitter, pungent, and } \\
\text { greener notes, and were } \\
\text { preferred by the Spanish } \\
\text { consumers. The USA } \\
\text { consumers liked the bland } \\
\text { Spanish refined olive oil, } \\
\text { and the Californian olive } \\
\text { oil that was characterized } \\
\text { by fruity, floral, and sweet } \\
\text { notes. }\end{array}$ \\
\hline $\begin{array}{l}\text { Vlontzos } \\
\text { and } \\
\text { Duquenne } \\
\text { (2014) }\end{array}$ & $\begin{array}{l}\text { Olive } \\
\text { oil }\end{array}$ & Greece & $\begin{array}{l}\text { Discrete } \\
\text { choice } \\
\text { experiment }\end{array}$ & $\begin{array}{l}\text { Greek consumers accept } \\
\text { payment premiums for } \\
\text { organic oils ( } 66.4 \%) \text { and } \\
\text { were willing to pay only } \\
\text { for olive oils processed by } \\
\text { either private companies or } \\
\text { cooperatives }(34.0 \%) \text {. }\end{array}$ \\
\hline $\begin{array}{l}\text { Yangui et } \\
\text { al. (2014) }\end{array}$ & EVOO & Spain & $\begin{array}{l}\text { Discrete } \\
\text { choice } \\
\text { experiment }\end{array}$ & $\begin{array}{l}\text { The most important } \\
\text { attributes affecting } \\
\text { consumers' preferences } \\
\text { towards EVOO were the } \\
\text { price and the product's } \\
\text { origin. }\end{array}$ \\
\hline $\begin{array}{l}\text { Ballco et al. } \\
(2015)\end{array}$ & EVOO & Spain & $\begin{array}{l}\text { Real } \\
\text { choice } \\
\text { experiment }\end{array}$ & $\begin{array}{l}\text { The results identified that, } \\
\text { apart from the price, the } \\
\text { origin of production, and } \\
\text { PDO were of great } \\
\text { importance. }\end{array}$ \\
\hline $\begin{array}{l}\text { Cabrera et } \\
\text { al. (2015) }\end{array}$ & EVOO & Spain & $\begin{array}{l}\text { Hedonic } \\
\text { price }\end{array}$ & $\begin{array}{l}\text { The results revealed that } \\
\text { EVOO prices were higher } \\
\text { for products whose labels } \\
\text { indicated the acidity, the } \\
\text { olive variety, and the } \\
\text { Andalusian logo for quality } \\
\text { certification. The PDO } \\
\text { quality certification was } \\
\text { not significant. }\end{array}$ \\
\hline $\begin{array}{l}\text { Del Giudice } \\
\text { et al. } \\
(2015)\end{array}$ & EVOO & Italy & $\begin{array}{l}\text { Existing } \\
\text { literature }\end{array}$ & $\begin{array}{l}\text { Overall, the results } \\
\text { indicated that the PDO, } \\
\text { PGI, organic certification, } \\
\text { brand, and taste were } \\
\text { important attributes that } \\
\text { affected the purchase of } \\
\text { EVOO. }\end{array}$ \\
\hline $\begin{array}{l}\text { Romo- } \\
\text { Muñoz et } \\
\text { al. (2015) }\end{array}$ & $\begin{array}{l}\text { Olive } \\
\text { oil }\end{array}$ & Chile & $\begin{array}{l}\text { Hedonic } \\
\text { price }\end{array}$ & $\begin{array}{l}\text { The results showed that the } \\
\text { attributes that most } \\
\text { positively influenced final } \\
\text { price were oil acidity level, } \\
\text { tin-can container for } \\
\text { imported oil, and origin. }\end{array}$ \\
\hline $\begin{array}{l}\text { Bernabéu } \\
\text { and Díaz } \\
\text { (2016) }\end{array}$ & $\begin{array}{l}\text { Olive } \\
\text { oil }\end{array}$ & Spain & $\begin{array}{l}\text { Conjoint } \\
\text { analysis }\end{array}$ & $\begin{array}{l}\text { The most preferred olive } \\
\text { oil was low priced, EVOO } \\
\text { and organic. The type of } \\
\text { bottle did not appear to be } \\
\text { relevant in the buying } \\
\text { decision process. }\end{array}$ \\
\hline
\end{tabular}


Table 1 (Continued)

\begin{tabular}{|c|c|c|c|c|}
\hline Reference & Product & Country & $\begin{array}{l}\text { Analytical } \\
\text { method }\end{array}$ & Key findings \\
\hline $\begin{array}{l}\text { Boncinelli } \\
\text { et al. } \\
(2016)\end{array}$ & EVOO & Italy & $\begin{array}{l}\text { Discrete } \\
\text { choice } \\
\text { experiment }\end{array}$ & $\begin{array}{l}\text { The attributes that most } \\
\text { influenced the } \\
\text { heterogeneity of choices } \\
\text { were the price, PDO, and } \\
\text { organic certification, while } \\
\text { limited importance was } \\
\text { attached to health claims } \\
\text { on the bottle. }\end{array}$ \\
\hline $\begin{array}{l}\text { Cacchiarelli } \\
\text { et al. } \\
(2016)\end{array}$ & $\begin{array}{l}\text { Olive } \\
\text { oil }\end{array}$ & Italy & $\begin{array}{l}\text { Hedonic } \\
\text { price }\end{array}$ & $\begin{array}{l}\text { The results indicated that } \\
\text { area of origin, } \\
\text { certifications of origin } \\
\text { (DOP/IGP), bottle size } \\
\text { (smaller sizes), and organic } \\
\text { were the factors that } \\
\text { played an important role in } \\
\text { the price formation for } \\
\text { olive oils in Italy. }\end{array}$ \\
\hline $\begin{array}{l}\text { Romo- } \\
\text { Muñoz et } \\
\text { al. (2017) }\end{array}$ & EVOO & Chile & $\begin{array}{l}\text { Discrete } \\
\text { choice } \\
\text { experiment }\end{array}$ & $\begin{array}{l}\text { The results from the utility } \\
\text { function allowed the } \\
\text { differentiation between the } \\
\text { two regimes. In the first } \\
\text { regime, higher utility was } \\
\text { assigned to higher prices } \\
\text { and consumers preferred } \\
\text { foreign products in smaller } \\
\text { containers, while in the } \\
\text { second regime, Chilean } \\
\text { olive oil in larger } \\
\text { containers was preferred. }\end{array}$ \\
\hline
\end{tabular}

\begin{tabular}{|c|c|c|c|c|}
\hline Reference & Product & Country & $\begin{array}{l}\text { Analytical } \\
\text { method }\end{array}$ & Key findings \\
\hline $\begin{array}{l}\text { Cavallo } \\
\text { and } \\
\text { Piqueras- } \\
\text { Fiszman, } \\
2016\end{array}$ & EVOO & $\begin{array}{l}\text { The } \\
\text { Netherlands } \\
\text { - Italy }\end{array}$ & $\begin{array}{l}\text { Conjoint } \\
\text { analysis }\end{array}$ & $\begin{array}{l}\text { Healthiness perception } \\
\text { was enhanced by EVOO } \\
\text { elements on the label, } \\
\text { such as organic } \\
\text { production, country of } \\
\text { origin and by consumer } \\
\text { traits such as familiarity } \\
\text { with the product and } \\
\text { sustainability concerns. }\end{array}$ \\
\hline $\begin{array}{l}\text { Roselli et } \\
\text { al. (2016) }\end{array}$ & $\begin{array}{l}\text { Olive } \\
\text { oil }\end{array}$ & USA & $\begin{array}{l}\text { Hedonic } \\
\text { price }\end{array}$ & $\begin{array}{l}\text { The results of the study } \\
\text { showed that extrinsic } \\
\text { olive oil cues, such as } \\
\text { bottle size (smaller } \\
\text { sizes), the EVOO type } \\
\text { of oil, organic, PDO/ } \\
\text { PGI, and some } \\
\text { countries of origin, } \\
\text { such as Italy, led to } \\
\text { significant differences } \\
\text { in price. }\end{array}$ \\
\hline $\begin{array}{l}\text { Sayadi et } \\
\text { al. (2016) }\end{array}$ & $\begin{array}{l}\text { Olive } \\
\text { oil }\end{array}$ & Spain & $\begin{array}{l}\text { Quality } \\
\text { Function } \\
\text { Deployment } \\
\text { method }\end{array}$ & $\begin{array}{l}\text { The findings suggested } \\
\text { that besides olive- } \\
\text { farming practices, the } \\
\text { olive-oil quality } \\
\text { attributes most } \\
\text { requested by consumers } \\
\text { incorporated } \\
\text { organoleptic (e.g. } \\
\text { acidity, flavor, color), } \\
\text { sociocultural (e.g. } \\
\text { creating employment in } \\
\text { rural areas, } \\
\text { maintenance of the } \\
\text { rural population) and } \\
\text { environmental } \\
\text { characteristics } \\
\text { (environmental } \\
\text { externalities). }\end{array}$ \\
\hline
\end{tabular}

Table 1 (Continued)

\begin{tabular}{|c|c|c|c|c|}
\hline Reference & Product & Country & $\begin{array}{l}\text { Analytical } \\
\text { method }\end{array}$ & Key findings \\
\hline $\begin{array}{l}\text { Yangui et } \\
\text { al. (2016) }\end{array}$ & EVOO & Spain & $\begin{array}{l}\text { Discrete } \\
\text { choice } \\
\text { experiment }\end{array}$ & $\begin{array}{l}\text { The results suggested } \\
\text { that Catalan consumers } \\
\text { perceived disutility } \\
\text { from the organic } \\
\text { attribute compared to } \\
\text { other production } \\
\text { system alternatives } \\
\text { (conventional and } \\
\text { PDO). Environmental } \\
\text { or health concerns were } \\
\text { not relevant to } \\
\text { consumer choices, as } \\
\text { conventional olive oil is } \\
\text { perceived to be a } \\
\text { healthy product per se. }\end{array}$ \\
\hline $\begin{array}{l}\text { Liberatore } \\
\text { et al. } \\
\text { (2017) }\end{array}$ & EVOO & Italy & $\begin{array}{l}\text { Conjoint } \\
\text { analysis }\end{array}$ & $\begin{array}{l}\text { The results identified } \\
\text { three main clusters; the } \\
\text { PDO EVOO consumers } \\
\text { ( } 27.2 \%) \text {, the PDO and } \\
\text { organic EVOO } \\
\text { consumers ( } 32.4 \%) \text {, } \\
\text { and consumers who } \\
\text { were indifferent to } \\
\text { certifications }(40.4 \%) \text {. }\end{array}$ \\
\hline $\begin{array}{l}\text { Carbone } \\
\text { et al. } \\
(2018)\end{array}$ & $\begin{array}{l}\text { Olive } \\
\text { oil }\end{array}$ & Italy & $\begin{array}{l}\text { Hedonic } \\
\text { price }\end{array}$ & $\begin{array}{l}\text { Main results indicated } \\
\text { that consumers valued } \\
\text { features directly related } \\
\text { to the product, to the } \\
\text { raw material used, to } \\
\text { the production process, } \\
\text { the type of producer, } \\
\text { and the production } \\
\text { area. On the contrary, } \\
\text { European quality } \\
\text { schemes, such as PDO } \\
\text { and organic production, } \\
\text { did not affect prices. }\end{array}$ \\
\hline $\begin{array}{l}\text { Cavallo et } \\
\text { al. (2018) }\end{array}$ & EVOO & Italy & $\begin{array}{l}\text { Hedonic } \\
\text { price }\end{array}$ & $\begin{array}{l}\text { Among other attributes, } \\
\text { results showed that } \\
\text { origin (PDO) and } \\
\text { territory, organic } \\
\text { certification, and } \\
\text { nutritional information } \\
\text { significantly affected } \\
\text { prices. In terms of } \\
\text { sensory profiles, fruity } \\
\text { and pungent tastes } \\
\text { affected prices. }\end{array}$ \\
\hline $\begin{array}{l}\text { Roselli et } \\
\text { al. (2018) }\end{array}$ & $\begin{array}{l}\text { Olive } \\
\text { oil }\end{array}$ & Brazil & $\begin{array}{l}\text { Hedonic } \\
\text { price }\end{array}$ & $\begin{array}{l}\text { The results showed that } \\
\text { the retail price of olive } \\
\text { oil was highly } \\
\text { influenced by branding, } \\
\text { labeling (mono-varietal } \\
\text { specification and } \\
\text { organic), and packaging } \\
\text { (smaller sizes). }\end{array}$ \\
\hline $\begin{array}{l}\text { Torres- } \\
\text { Ruiz et al. } \\
(2018)\end{array}$ & $\begin{array}{l}\text { Organic } \\
\text { EVOO }\end{array}$ & Spain & $\begin{array}{l}\text { Conjoint } \\
\text { analysis }\end{array}$ & $\begin{array}{l}\text { The results suggested } \\
\text { that the organic } \\
\text { attribute was not highly } \\
\text { valued or appreciated } \\
\text { by Spanish consumers. }\end{array}$ \\
\hline
\end{tabular}

For example, in Castile La-Mancha (Spain), Bernabéu and Díaz (2016) explored consumer preferences for olive oil and identified the main attributes of differentiation. The most important attributes that affected the purchase decision were low-priced oils, the EVOO type of oil, and ones that carried organic certification. Conversely, in Catalonia (north-east Spain), Yangui et al. (2016) investigated the role of psychological factors in building the consumer's behavioral decision process towards EVOO and found disutility for organic oils. Similarly, in six different Spanish cities (Madrid, Barcelona, Sevilla, Sala- 
manca, Ovieo and Valencia), Torres-Ruiz et al. (2018) examined the barriers to consuming organic EVOO and found that organic certification was not highly valued or appreciated by Spanish consumers. Concerning the origin of production and the PDO quality certifications, in Zaragoza (Spain), Ballco et al. (2015) examined consumer preferences for EVOO and assessed WTP estimates using an RCE. Results indicated that price was the most important attribute, followed by the origin of production and the PDO quality certification. In Catalonia (Spain), Yangui et al. (2014) found similar results (i.e., price and product origin) for EVOOs, using a discrete choice experiment (DCE). In the Andalusian region (Spain), Cabrera et al. (2015), using an HP approach, illustrated that labels indicating the acidity level, the olive variety, and those carrying the Andalusian logo for quality certification increased EVOO prices. The European PDO quality certification did not affect EVOO prices. Again in Andalusia (Spain), Sayadi et al. (2016) identified consumer requirements regarding different quality attributes of olive-oil through a quality function deployment approach. Results identified that, as well as olive oil farming practices, consumers valued the organoleptic aspects of the olive oil (e.g., acidity level, flavor, color), sociocultural aspects (e.g., creating employment in rural areas), and environmental factors (e.g., environmental externalities). Finally, in terms of organoleptic characteristics, through a mapping of preferences approach, Vázquez-Araújo et al. (2014) compared consumer preferences for Spanish and US consumers. Results revealed that bitter, pungent and greener notes were mostly preferred by Spanish consumers, while refined oils, fruity, floral, and sweet notes were preferred by US consumers.

In comparison to the high diversity of Spanish consumer preferences, studies conducted in Italy show more homogeneity in terms of preferences for olive oil quality attributes. For instance, Panico et al. (2014) investigated consumer preferences for EVOO in Italy and suggested that the PDO and PGI quality certification, organic certification, production methods and organoleptic characteristics highly affected purchase decisions. Del Giudice et al. (2015) used a meta-analysis of consumers' stated preferences and found that PDO, PGI, organic certification, brand, and taste were important attributes that affected the purchase of EVOOs. Boncinelli et al. (2016) identified groups of Italian consumers with similar preferences using a latent class model. Results suggested that the most important attributes for consumers were the price, PDO and organic certification. Using a hedonic price approach, Cacchiarelli et al. (2016) identified that the area of origin, certification of origin (PDO/PGI), organic certification, and bottle size (smaller sizes) affected the formation of olive oil prices in Italy. Similarly, using a hedonic price approach, Cavallo et al. (2018) identified that origin (PDO) and territory, organic certification, taste (i.e., fruity and pungent), and nutritional information were attributes that significantly affected prices in Italy. Liberatore et al. (2017) through k-means cluster analysis identified three groups of Italian consumers with similar preferences: PDO EVOO seekers, PDO and organic EVOO seekers, and consumers who are indifferent to quality certifications. Italian consumers who were indifferent towards European quality schemes (e.g., PDO/PGI and organic) were also identified in the study by Carbone et al. (2018). However, consumers valued features related to the raw material used, production processes, the type of producer (e.g., traditional), and the production area. In Italy and the Netherlands, Cavallo and Piqueras-Fiszman (2016) examined visual elements of packaging that shaped healthiness evaluations by EVOO consumers. Results suggested that the healthiness perceptions by consumers from both countries were enhanced by organic production, country of origin, sustainability aspects, and familiarity with the product. In Greece, Vlontzos and Duquenne (2014) highlighted the role that socio-economic and spatial attributes of consumer households exert on their choices regarding not only the supply modes but also the price consumers were willing to pay for different categories of olive oil. Results sug- gested that Greek consumers were willing to pay premium prices for organic olive oils (66.4\%), and olive oils that were processed by either private organisations or cooperatives (34.0\%). In Chile, Romo-Muñoz et al. (2015) determined the implicit values of the most relevant attributes of olive oil on the final price charged by supermarkets using a hedonic price methodology. Results illustrated that oil acidity, the tin-can container for imported oil and origin were the attributes that most positively influenced the final price. Another study by Romo-Muñoz et al. (2017) analyzed consumer preferences and their WTP for EVOO attributes. Results from a random parameter logit model categorized consumer preferences under two regimes. In the first regime, consumers preferred higher prices and imported EVOO in small containers, while under the second regime Chilean olive oil in large containers was the most preferred. Roselli et al. (2016), using an HP approach, examined the main extrinsic quality cues (i.e., size of the container, product category, organic certification, geographical indications, country of origin, and brand) that affected olive oil prices in the USA. Results suggested that quality cues, such as bottle size (smaller sizes), the EVOO type of oil, organic, PDO and PGI, and country of origin (mainly from Italy) affected prices. Finally, a more recent study by Roselli et al. (2018) in Brazil, examined whether, and to what extent, extrinsic cues impacted on the retail prices of olive oil by using a hedonic price approach. The overall results showed that the retail price of olive oil was highly influenced by branding, labeling, and packaging.

Based on the findings from these earlier studies, we hypothesize the following: (H1). There is a relationship between the premium prices derived from the HP model and the utility/willingness to pay estimates from the RCE for the common attributes of both approaches (i.e., the origin of production and the PDO quality certification).

\section{Materials and methods}

\subsection{Data collection}

The data for this research were collected in January 2015 and were executed in two steps. The first step consisted of exploring previous studies reported in Table 1 and launching an online pilot survey $(n=594)$ to examine the consumption of different types of olive oils, the importance of several attributes and socio-demographic characteristics. The results from this first step suggested that EVOO was the type of oil most consumed in Spanish households (78.72\%). Hence, this study used EVOO as a reference because of the high familiarity among Spanish consumers. In addition, findings from the literature and the online pilot survey indicated that the most important olive oil attributes for consumers, were price, origin of production, local production and territory, and the PDO quality certification. Results also indicated that EVOO was mainly purchased at supermarkets $(64.36 \%)$, directly from the producers/cooperatives $(39.70 \%)$, and hypermarkets $(26.52 \%)$

The second step involved exploring the presence of EVOOs and the availability of the attributes defined in the first step in the local market. For that, we created a database that collected information regarding EVOOs and attributes available in various hypermarkets and supermarkets in Zaragoza (Spain). To guarantee the representativeness of the sample, the data were collected at the physical stores of seven different retail chain stores (i.e., hypermarkets, neighborhood, and discount stores), which accounted for $56.4 \%$ of the sector's market share (Montes, 2018, 2019). ${ }^{1}$ The final sample included 260 EVOOs, which were included in the HP model, as shown in Table 2.

1 It is worth mentioning that while in countries such as the United Kingdom a handful of large operators control more than $80 \%$ of the market, in Spain the local chains and small distribution companies still distribute about $45 \%$ of the pie (Ballco and de-Magistris, 2018). 
Table 2

Characteristics of the sample for the hedonic price model.

\begin{tabular}{|c|c|c|c|c|c|}
\hline & & \multicolumn{2}{|c|}{ Attribute levels } & \multicolumn{2}{|c|}{$\begin{array}{l}\text { No. of } \\
\text { observations } \\
(\%)\end{array}$} \\
\hline \multicolumn{2}{|l|}{ EVOO price } & \multicolumn{2}{|c|}{$\begin{array}{l}\text { Price in } € / \text { litter } \\
\text { (L) }\end{array}$} & \multicolumn{2}{|c|}{$260(100)$} \\
\hline \multicolumn{2}{|l|}{ Bottle size } & \multicolumn{2}{|c|}{$\begin{array}{l}\text { Quantity in } \\
\text { milliliters (ml) }\end{array}$} & \multicolumn{2}{|c|}{$260(100)$} \\
\hline \multirow{2}{*}{\multicolumn{2}{|c|}{ Brand }} & \multicolumn{2}{|c|}{ Leader } & \multicolumn{2}{|c|}{$232(89.23)$} \\
\hline & & \multicolumn{2}{|c|}{$\begin{array}{l}\text { Private } \\
\text { (supermarket } \\
\text { brand) }\end{array}$} & \multicolumn{2}{|c|}{$28(10.77)$} \\
\hline \multicolumn{2}{|c|}{ Origin of production ${ }^{a}$} & \multicolumn{2}{|c|}{ Indicated } & \multicolumn{2}{|c|}{$132(50.77)$} \\
\hline \multicolumn{2}{|c|}{ Protected Designation of Origin (PDO) } & \multicolumn{2}{|c|}{ PDO } & \multicolumn{2}{|c|}{$47(18.08)$} \\
\hline \multicolumn{2}{|l|}{ Organic } & \multicolumn{2}{|c|}{ Organic } & \multicolumn{2}{|c|}{$13(5.00)$} \\
\hline \multirow{2}{*}{\multicolumn{2}{|c|}{$\begin{array}{l}\text { Olive variety } \\
\text { Retail chain }\end{array}$}} & \multirow{2}{*}{\multicolumn{2}{|c|}{$\begin{array}{l}\text { Indicated } \\
\text { Hypermarkets }\end{array}$}} & \multirow{2}{*}{\multicolumn{2}{|c|}{$106(40.77)$}} \\
\hline & & & & & \\
\hline & & \multicolumn{2}{|c|}{ Carrefour } & \multicolumn{2}{|c|}{50 (19.23) } \\
\hline & & \multicolumn{2}{|c|}{ Hipercor } & \multicolumn{2}{|c|}{$95(36.54)$} \\
\hline & & \multicolumn{2}{|c|}{$\begin{array}{l}\text { Alcampo/Simply } \\
\text { c }\end{array}$} & \multicolumn{2}{|c|}{$83(31.92)$} \\
\hline & & $\begin{array}{l}\text { Discour } \\
\text { Dia (B } \\
\text { Neighb } \\
\text { store }\end{array}$ & $\begin{array}{l}\text { line) } \\
\text { ood }\end{array}$ & \multicolumn{2}{|c|}{$5(1.92)$} \\
\hline & & Mercac & & $4(1$. & \\
\hline & & El Arbc & & $11(4$ & \\
\hline & & Eroski & & $12(4$ & \\
\hline Container & & Plastic & & 121 & 54) \\
\hline & & Glass & & 112 & 08) \\
\hline & & Tetra $\mathrm{F}$ & k/Can & $27(1$ & \\
\hline & No. cases (\%) & $\frac{\text { Mean }}{\mathrm{b}}$ & $\frac{\text { Std. }}{\text { dev. }}$ & $\underline{\text { Min }}$ & $\underline{\text { Max }}$ \\
\hline Sample & $260(100)$ & $6.46 €$ & 4.79 & $\begin{array}{l}1.99 \\
€\end{array}$ & $\begin{array}{l}33.86 \\
€\end{array}$ \\
\hline $250 \mathrm{ml}$ & $2(0.77 \%)$ & $\begin{array}{l}8.56 \\
€\end{array}$ & 0.85 & $\begin{array}{l}7.96 \\
€\end{array}$ & $\begin{array}{l}9.16 \\
€\end{array}$ \\
\hline $500 \mathrm{ml}$ & $65(25.00 \%)$ & $\begin{array}{l}11.42 \\
€\end{array}$ & 6.50 & $\begin{array}{l}1.99 \\
€\end{array}$ & $\begin{array}{l}33.86 \\
€\end{array}$ \\
\hline $750 \mathrm{ml}$ & $50(19.23 \%)$ & $\begin{array}{l}6.35 \\
€\end{array}$ & 2.53 & $\begin{array}{l}3.09 \\
€\end{array}$ & $\begin{array}{l}19.21 \\
€\end{array}$ \\
\hline $1000 \mathrm{ml}$ & $90(34.62 \%)$ & $\begin{array}{l}4.20 \\
€\end{array}$ & 2.21 & $\begin{array}{l}2.59 \\
€\end{array}$ & $\begin{array}{l}22.96 \\
€\end{array}$ \\
\hline$>1000 \mathrm{ml}$ & $53(20.38 \%)$ & $\begin{array}{l}4.25 \\
€\end{array}$ & 1.78 & $\begin{array}{l}2.58 \\
€\end{array}$ & $\begin{array}{l}14.74 \\
€\end{array}$ \\
\hline
\end{tabular}

Note: ${ }^{a}$ We did not include levels of origin because all EVOO came from Spain. ${ }^{\mathrm{b}}$ Mean prices per liter of EVOO. ' ${ }^{\mathrm{c}}$ In 2015, Alcampo was a hypermarket and Simply a neighborhood store. Today these two stores have merged under Alcampo. In order not to create confusion we merged the EVOOs under Alcampo.

EVOO prices varied depending on the size of the bottle, from a minimum of $€ 1.99$ to a maximum of $€ 33.86$, with an average price of $€ 6.46 /$ liter (L). The content varied between 250 and $5000 \mathrm{~mL}(\mathrm{ml})$, with an average of approximately $1400 \mathrm{ml}$. The most common bottle size found was $1000 \mathrm{ml}(34.62 \%)$ mainly in plastic (46.54\%) followed by $500 \mathrm{ml}(25.00 \%)$, and bottle sizes of more than $1000 \mathrm{ml}(20.38 \%)$. The hypermarket provided $87.69 \%$ of the total number of references followed by the neighborhood stores, with $10.39 \%$ of the EVOOs. Discount stores had a lower number of references compared to hypermarkets, and accordingly, their contribution to the total number of observations was lower (1.92\%) with respect to the neighborhood stores. Concerning the brand name differences, records implied that EVOOs were mostly marketed under the processors' leading brands $(89.23 \%)$ in comparison to own distributors' private brands (10.77\%). In terms of the origin of production labels, about $50.77 \%$ of the EVOOs indicated the origin of the oil, although without specifying whether the origin referred to the production origin or the location of the bottling com- pany. Surprisingly, only $18.08 \%$ of the EVOO in the market bore the PDO quality certification and about $5.00 \%$ carried organic certification. Finally, records implied that about $40.77 \%$ of the EVOOs indicated the olive variety on the label.

\subsection{Choice experiment: product and attribute selection}

The preliminary results from the literature review, the online pilot survey, and the database suggested three attributes should be included in the RCE design: price, the origin of production and the PDO quality certification. We selected a 1L bottle of EVOO because of its high prevalence in the market and high purchase frequency by consumers. To establish the price levels, information on the EVOO sold in different supermarkets was used, and three price levels were set ( 3,5 and $8 € / \mathrm{L})$, considering that the average price of one $1000 \mathrm{ml}$ bottle was $4.20 € / \mathrm{L}$, with a minimum of approximately $3 €$ and a maximum of $8 € .{ }^{2}$ For the production origin, three levels were also established: produced in the county ${ }^{3}$ (county), produced in other counties in the region (region) or produced in the rest of Spain (Spain). Finally, PDO certification had two levels, indicating whether or not the EVOO carried PDO certification. The attributes selected for the real choice experiment and their levels are summarized in Table 3.

For these attributes and levels, we generated a Bayesian efficient design, ${ }^{4}$ with 12 possible combinations randomly divided into three blocks. Each respondent was asked to make four choices consisting of two designed alternatives and a no-buy option. It is worth mentioning that all the combinations of EVOOs presented in the choice tasks (e.g., an EVOO from the county with PDO) were based on information from real products existing in the marketplace. All different EVOO bottles from the three blocks were present in the experimental room (without the brand names). After completing the experiment, participants could see the bottles and their corresponding information, including their brand names.

\subsection{Experimental procedure}

The RCE was conducted over 18 sessions, involving a total of 216 participants. Respondents were informed that at the end of the experiment they would receive $15 €$ to purchase a bottle of EVOO at the corresponding price. They received clear information about the EVOOs and the attributes presented in the different choice tasks and were asked to choose four times between two EVOOs or the no-buy option. Visual choice cards with different choice tasks were presented and the real EVOO bottles with all combinations of attributes, as presented in the choice tasks, were displayed (without brand names). The final task was to randomly select a binding choice task and choose one out of the choice tasks from the whole experiment. One binding scenario was selected, and this would be the binding choice task for the entire session. Respondents received $15 €$ to purchase the olive oil selected in the binding choice task and paid the corresponding price. Finally, participants were asked to complete a short questionnaire regarding olive oil consumption, purchase habits for EVOO and their personal characteristics. ${ }^{5}$ At the end of the experiment, participants received the chosen EVOO from the binding scenario and had to pay the corresponding price.

2 The maximum price level excludes gourmet EVOOs with different varieties, EVOOs that have won national and international awards, and EVOOs with both organic and PDO labels on the same bottle.

3 An olive oil-producing county close to Zaragoza was selected.

4 To set the priors for the Bayesian specification, we used the information gathered from pilot choice experiments. The estimated coefficient for the means and standard deviations for these data were used as prior values in Ngene.

5 The results of the questionnaire are not included in this research paper. 
Table 3

Extra virgin olive oil attributes and levels.

\begin{tabular}{ll}
\hline Attribute & Level \\
\hline $\begin{array}{l}\text { Price }(€ / \mathrm{L}) \\
\text { Origin of production }\end{array}$ & $\begin{array}{l}3 € / \mathrm{L}-5 € / \mathrm{L}-8 € / \mathrm{L} \\
\text { Produced in the county (county) } \\
\text { Produced in other counties of the region (region) } \\
\text { Produced in Spain —-the rest of Spain (Spain) } \\
\text { Carries the PDO certification } \\
\text { Designation of origin }\end{array}$ \\
& Does not carry the PDO certification \\
\hline
\end{tabular}

\subsection{Econometric specifications}

\subsubsection{Hedonic price model}

The hedonic price model comes from the theory of demand by Lancaster (1966), which states that consumers derive utility directly from the characteristics that a product possesses rather than from the product itself:

$U(X)=U\left(x_{1}, x_{2}, \ldots, x_{k}\right)$

Taking into account that each consumer chooses an optimal bundle of attributes to maximize utility, subject to a budget constraint, Rosen (1974) further developed this theory to obtain the standard hedonic price model:

$P(X)=P\left(x_{1}, x_{2}, \ldots, x_{k}\right)$

where $\mathrm{P}$ is the price of a product and $X=x_{1}, x_{2}, \ldots, x_{k}$ is a vector of $k$ attributes that comprise the product.

The implicit price of an additional unit of an attribute is determined as the partial derivative of the hedonic price function with respect to that particular attribute. For continuous attributes, the consumer chooses the bundle where his/her indifference curve is tangent to the price gradient, $\partial P / \partial z_{j}$, for each attribute. Therefore, the marginal willingness to pay for a change in an EVOO attribute is equal to the derivative of the hedonic price function with respect to that attribute (Costanigro et al., 2007). In our case, the characteristics of the EVOO $\left(x_{k}\right)$ in the market are presented in Table 4.

To estimate the implicit prices, or willingness to pay for the attributes, we must assume a functional for Eq. (2). First, the linear specification can be considered:

$P(X)=\gamma_{0}, \gamma_{1} x_{1}+\gamma_{2} x_{2}+\ldots+\gamma_{k} x_{k}$

where $\gamma_{k}$ are the parameters to estimate the implicit prices or willingness to pay. However, in the literature, other functional forms such as the semi-logarithmic (log-lin), the logarithmic (lin-log) and the double-logarithmic $(\log -\log )$ are frequently used. Since economic theory does not solve the problem as to which is the most suitable functional form of the hedonic price function, it is a decision that researchers have to make empirically. The Box-Cox transformation approach has usually been applied for this purpose (Box and Cox, 1964). The approach nests alternative functional forms, by adding non-linear parameters, $\theta$ and $\lambda$ on the dependent and independent variables, respectively expressed as:

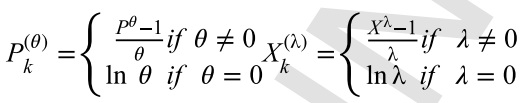

The transformation provides four possible functional outcomes: (i) linear, when $\theta=\lambda=1$; (ii) semi-logarithmic, when $\theta=0$ and $\lambda=1$; (iii) double-logarithmic, $\theta=\lambda=0$ and (iv) linear-logarithmic, $\theta=1$ and $\lambda=1$. However, individual and joint tests on the Box-Cox parameters may lead to inconclusive results.
Table 4

Description of variables used in the estimation of the hedonic price function

\begin{tabular}{|c|c|c|}
\hline EVOO characteristics & $\begin{array}{l}\text { Attribute } \\
\text { variables }\end{array}$ & Definition \\
\hline EVOO price & Price & $\begin{array}{l}\text { Continuous ( } € \text { per } \\
\text { litter) }\end{array}$ \\
\hline Bottle size & Quantity & $\begin{array}{l}\text { Continuous } \\
\text { (milliliter) }\end{array}$ \\
\hline Brand & Leader & $\begin{array}{l}1=\text { Leader } \\
0=\text { Private } \\
\text { (Supermarket brand) }\end{array}$ \\
\hline Origin of production ${ }^{a}$ & Origin & $\begin{array}{l}1=\text { Indicated } \\
0=\text { otherwise }\end{array}$ \\
\hline $\begin{array}{l}\text { Protected Designation of Origin } \\
\text { (PDO) }\end{array}$ & PDO & $\begin{array}{l}1=\text { Yes } \\
0=\text { otherwise }\end{array}$ \\
\hline Organic certification & Organic & $\begin{array}{l}1=\text { Yes } \\
0=\text { otherwise }\end{array}$ \\
\hline Olive variety & Variety & $\begin{array}{l}1=\text { Indicated } \\
0=\text { otherwise }\end{array}$ \\
\hline \multirow[t]{9}{*}{ Retail chain } & $\begin{array}{l}\text { Hypermarket } \\
\text { Carrefour }\end{array}$ & $\begin{array}{l}1=\text { Carrefour } \\
0=\text { otherwise }\end{array}$ \\
\hline & Hipercor & $\begin{array}{l}1=\text { Hipercor } \\
0=\text { otherwise }\end{array}$ \\
\hline & Alcampo/Simply & $\begin{array}{l}1=\text { Alcampo } / \text { Simply } \\
0=\text { otherwise }\end{array}$ \\
\hline & $\begin{array}{l}\text { Neighborhood } \\
\text { store }\end{array}$ & \\
\hline & Mercadona & $\begin{array}{l}1=\text { Mercadona } \\
0=\text { otherwise }\end{array}$ \\
\hline & El Arbol & $\begin{array}{l}1=\mathrm{El} \text { Arbol } \\
0=\text { otherwise }\end{array}$ \\
\hline & Eroski & $\begin{array}{l}1=\text { Eroski } \\
0=\text { otherwise }\end{array}$ \\
\hline & Discount & \\
\hline & Dia (Baseline) & $\begin{array}{l}(\alpha) \text { is expressed as } \\
\text { constant }\end{array}$ \\
\hline \multirow[t]{3}{*}{ Container } & Plastic & $\begin{array}{l}1=\text { Plastic } \\
0=\text { otherwise }\end{array}$ \\
\hline & Glass & $\begin{array}{l}1=\text { Glass } \\
0=\text { otherwise }\end{array}$ \\
\hline & $\begin{array}{l}\text { Tetra Pack/Can } \\
\text { (Baseline) }\end{array}$ & $\begin{array}{l}(\alpha) \text { is expressed as } \\
\text { constant }\end{array}$ \\
\hline
\end{tabular}

Note: ${ }^{\text {a }}$ We did not include levels of origin because all EVOO came from Spain.

According to the previous literature (Ballco and de-Magistris, 2018; Cabrera et al., 2015; Sanjuán-López et al., 2009) the Vuong test (Vuong, 1989) may be applied to select the functional form that best fits the data. The Vuong test determines the predicted probabilities of two models, choosing the best values in terms of log-likelihood and the variance estimate of their difference. For each functional form $i$, the likelihood ratio is expressed as:

$L R^{i}=\left(\lambda_{1} \theta_{l}, \lambda_{\mathrm{m}} \theta_{m}\right)=l l_{l}^{i}-l l_{m}^{i}$

where $l, m$ are one of any of the four models $(m)$ defined by the Box-Cox transformation and the $l_{m}$ is the log-likelihood function for observation $i$ evaluated at the parameter estimates of the model $m$. The Vuong test is then given by:

Vuong $=\frac{\sqrt{n}\left[\frac{1}{n} \Sigma_{i=1}^{n} L R_{i}\right]}{\sqrt{\frac{1}{n}} \sum_{i=1}^{n}\left(L R_{i}-\overline{L R_{i}}\right)^{2}}$

where $n$ is the number of observations. The test is normally distributed, thus, values larger than the critical $N_{\alpha / 2}$ (with $\alpha$ the significance level) favor model $l$, negative values $-N_{\alpha / 2}$ are in favor of model $m$ 
and Vuong $\leq N_{\alpha / 2}$ indicates no significant differences between the two models.

\subsubsection{Real choice experiment modeling}

Discrete Choice Experiment (DCE) is based on the Lancaster consumer theory of utility maximization (Lancaster, 1966), where the total utility depends on the characteristics of the product (Eq. (1)). DCEs are one of the most popular stated-preference methods used in consumer behavior to investigate individuals' WTP for a certain good or service because they evaluate different attributes and levels simultaneously. Moreover, this approach is similar to a real purchasing situation where consumers are asked to make trade-offs between products characterized by different attributes (Lusk and Schroeder, 2004). DCEs provide several hypothetical purchasing scenarios. In each scenario, participants are asked to make choices between alternatives that represent products with different attributes and levels with a no-buy option. The familiarity of the decision mechanism in a DCE is one of the main advantages of this approach. A limitation, however, of hypothetical DCE is that it may lead to hypothetical bias (Murphy et al., 2005). The absence of an economic commitment in hypothetical methods can lead to a source of inconsistency, generally over-estimation, in individual WTP estimations, as compared to non-hypothetical approaches, such as real choice experiments. To explain, hypothetical bias is the difference between the individuals' WTP from the hypothetical and non-hypothetical evaluation methods (Bazzani et al., 2017; Carpenter and Harrison, 2004; Murphy et al., 2005). Hence, to mitigate hypothetical bias in DCEs, several studies implement RCEs, where one of the choice tasks is randomly chosen as binding after the respondents have completed all of the choice tasks (Alfnes et al., 2006; Bazzani et al., 2017; Chang et al., 2009; de-Magistris and Gracia, 2014; Hamukwala et al., 2019). In addition, real products are used, and participants have to buy the product they choose in the randomly selected binding choice task, unless they choose the no-buy option. Previous research has demonstrated that incentive compatibility in RCEs can help mitigate hypothetical bias, providing better approximations of consumers' actual WTP (Chang et al., 2009; Grebitus et al., 2013; Loomis et al., 2009; Volinskiy et al., 2009; Yue and Tong, 2009). Hence, in this research, we use an RCE.

According to Lancaster (1966), consumers' utility is known to the individual but not to the researcher who observes some attributes while the rest are treated as stochastic within the random utility model by Mcfadden (1974). Then, the utility is taken as a random variable where the utility from the nth individual facing a choice among $j$ alternatives within choice task $J$ in each of $t$ choice occasions can be represented as:

$U_{n j t}=V_{n j t}+\varepsilon_{n j t}=\beta_{n} X_{n j t}+\varepsilon_{n j t}$

where $U_{n j}$ is the $n$th consumer's utility for choosing alternative $j, V_{n j t}$ is the systematic portion of the utility function that depends on $X_{n j t}$ and $\beta_{n}$ , where $X_{n j t}$ is a vector of product attributes (e.g., price, origin of production and PDO) that are observed by the analyst on choice occasion $t$, $\beta_{n}$ are the coefficients to be estimated, and $\varepsilon_{n j}$ is an unobserved random term that is distributed following an extreme value type I (Gumbel) distribution Independently and Identically Distributed (i.i.d) over alternatives and independent of $\beta X_{n j t}$. In our empirical specification, the utility function includes, as explanatory variables, the product attributes in the choice experiment, as well as an alternative-specific constant $(\alpha)$ representing the "A" and "B" choice alternatives. The utility function is specified as follows:

$$
\begin{aligned}
U_{n j t}= & \alpha+\beta_{1} \text { Price }_{n j t}+\beta_{2} \text { County }_{n j t} \\
& +\beta_{3} \text { Region }_{n j t}+\beta_{4} \text { PDO }_{n j t}+\varepsilon_{n j t}
\end{aligned}
$$

The alternative-specific constant $\alpha$ enters the model as a dummy variable, taking the value of one for the designed alternatives, and zero otherwise. The price variable represents the different price levels that consumers face in the choice tasks. The other attribute levels enter in the model as dummy variables (county, region and PDO). In particular, the county and region variables were set equal to one if the EVOO was produced in this geographical area, and zero otherwise. In the same way, the PDO attribute is coded as one if the olive oil has this certification, and zero otherwise. The remaining variables are specified as in Eq. (7).

Traditionally, based on Mcfadden (1974), a multinomial logit (MNL) model assumes that consumers have homogeneous preferences in terms of taste. However, to relax this assumption and allow that consumer preferences are heterogeneous in taste, more flexible discrete choice models, such as the Random Parameter Logit (RPL) model could be specified. The RPL model allows for random taste variation across individuals, through the distribution of random parameters; it relaxes the assumption of independence from irrelevant alternatives and allows for correlation among unobserved factors over time (Train, 2003). As result, the RPL model was applied. Since our choice experiment consists of two designed alternatives and a no-buy option, correlation across utilities likely exists. This correlation can be generated because the no-buy option is experienced by the consumer in a real-life setting while the experimental alternatives are designed by the researcher and vary across choice tasks. In other words, the experimentally designed alternatives could share an extra error component that is not presented in the utility of the experienced alternative (Scarpa et al., 2007). To take this extra variance of experimentally designed alternatives into account, an additional error component in the RPL model must be included, resulting in an error component random parameter logit (EC-RPL) model. This approach has been used successfully in several empirical applications because it is parsimonious (it only requires one extra parameter) and improves the model fit (Campbell, 2007; Hess et al., 2009; Scarpa et al., 2007; Scarpa et al., 2008). Thus, we also estimate an error component random parameter logit (EC-RPL) model. An EC-RPL is estimated to take into account the shared extra error component that is not present in the utility of the experienced alternatives (Scarpa et al., 2007). Therefore, we also specify an EC-RPL model, assuming correlation across taste parameters (Scarpa and Del Giudice, 2004). To better understand consumer valuation patterns, marginal WTP estimates are also calculated.

In this context, the marginal WTP is the price change associated with an increase in a given attribute and can be calculated as the negative ratio of the partial derivative of the utility function with respect to the attribute of interest, divided by the derivative of the utility function with respect to the price variable, represented as:

$\mathrm{WTP}_{\text {Attribute }}=-\frac{\frac{\partial \mathrm{U}_{\mathrm{njt}}}{\partial \text { Attribute }}}{\frac{\partial \mathrm{u}_{\mathrm{njt}}}{\partial \text { Price }}}=-\frac{\beta_{\text {Attibute }}}{\beta_{\text {Price }}}$

\section{Results}

\subsection{Hedonic price analysis}

The first step includes the estimation of the Box-Cox price regression (Eq. (4)) using the variables in Table 4 and estimated with STATA 10.0. The second step estimated testing of the possible equation specifications. Table 5 provides the results of this test, indicating that three possible functional forms are not rejected.

In addition, we also applied the Vuong test (Table 6) to finally select the best functional form. The results of the Vuong test indicate that both the semi-logarithmic (log-lin) and the double-logarithmic (log-log) functional forms are suitable. Although Table 6 shows that the 
Table 5

Box-Cox transformation.

\begin{tabular}{lllll}
\hline $\begin{array}{l}\text { Functional } \\
\text { form }\end{array}$ & $\begin{array}{l}\lambda \\
\text { value }\end{array}$ & $\begin{array}{l}\lambda \\
\text { value }\end{array}$ & $\begin{array}{l}\text { LR-statistic chi 2 (p- } \\
\text { value) }\end{array}$ & Result \\
\hline Log-lin & 0 & 1 & $0.04(0.84)$ & Not Rejected \\
Lin-log & 1 & 0 & $2.98(0.08)$ & Rejected \\
Lin-lin & 1 & 1 & $0.02(0.89)$ & Not Rejected \\
Log-log & 0 & 0 & $-8.86(1.00)$ & Not Rejected \\
\hline
\end{tabular}

Table 6

Vuong's test results.

\begin{tabular}{lll}
\hline Ho: & Vuong Statistic & Accepted form \\
\hline Log-lin vs. lin-log & $-81.36^{*}$ & Log-lin \\
Log-lin vs. lin-lin & -0.00 & - \\
Log-log vs. log-lin & $-2.63^{*}$ & Log-log \\
Log-log vs. lin-log & -0.00 & - \\
Lin-log vs. lin-lin & -0.00 & - \\
Lin-lin vs. log-log & -0.00 & - \\
\hline
\end{tabular}

Note: *Indicates the values are higher or lower than the critical values of 1.96 and -1.96 respectively, rejecting the null hypothesis of no-differences among functional forms.

best specification is the double-logarithm (log-log), additional statistical parameters have been performed to verify which of the functional forms best fits the model. The log-likelihood values indicated that the double-logarithmic functional form was superior $(-439.42)$ to the other alternative (-443.94). Moreover, Goodness-of-fit $\left(\mathrm{R}^{2}\right)(0.64)$ and the adjusted $R^{2}$ of $(0.62)$ were higher and significant $(F$-statistic $<0.01)$ while the Akaike and Schwarz information criterion was lower than the log-lin model, respectively. In addition, the double-logarithmic form shows no problem with the normality of residuals (probability of Jarque-Bera statistic of 0.00).

The Heteroscedasticity was tested using the Breusch-Pagan-Godfrey and White test statistic and the null hypothesis for the homoscedasticity in the error term was rejected (probability F-statistic 0.00), which indicates heteroscedasticity problems. White's robust estimation strategy to obtain the parameter standard errors was used to solve this problem. Estimation results for the double-logarithmic functional form are presented in Table 7.

The only continuous variable (quantity) was negative and statistically significant at $1 \%$ with a coefficient of -0.08 . Taking into account the double-logarithmic form of the equation, the coefficient of a continuous variable such as quantity can be directly interpreted in terms of elasticities. Hence, a negative and less than one coefficient means that an increase in the total amount of the product contained in the package leads to a less-than-proportional decrease in its price. This result is expected since a discount on a unit price is usually given when a larger quantity of product is purchased. The remaining variables in the hedonic price model are introduced as dummy variables. Considering this, the coefficient of a dummy variable can be transformed into the percentage change in price ${ }^{6}$ due to the presence of a given quality attribute (marginal effect).

The different type of chains where the EVOO is sold significantly affected product prices, and in particular the hypermarkets (Hipercor +34.99 and Carrefour +10.52) compared to most neighborhood and discount stores. When investigating the other extrinsic characteristics of EVOO, the leading brand in comparison to the own distributors' private brand also showed a substantial influence on price $(+32.31 \%)$. In addition, the olive variety and indication of the EVOO origin of produc-
Table 7

Results from the hedonic price model.

\begin{tabular}{llll}
\hline Hedonic price model & & & \\
& Coefficient & Standard Error & Marginal effect (\%) \\
\hline Constant $(\alpha)$ & $1.90^{* * *}$ & 0.31 & - \\
Quantity & $-0.08^{* * *}$ & 0.04 & -7.69 \\
Retail chains & & & \\
Carrefour & $0.10^{* *}$ & 0.05 & +10.52 \\
Hipercor & $0.30^{* * *}$ & 0.06 & +34.99 \\
Mercadona & -0.02 & 0.15 & NS \\
El arbol & $0.12^{* * *}$ & 0.06 & +12.75 \\
Alcampo & -0.02 & 0.06 & NS \\
Eroski & -0.01 & 0.08 & \\
Quality labels & & & +32.31 \\
Brand-Leader & $0.28^{* * *}$ & 0.06 & +9.42 \\
Olive variety & $0.09 *$ & 0.05 & +8.31 \\
Origin of production & $0.08^{*}$ & 0.05 & NS \\
PDO & 0.05 & 0.06 & +12.75 \\
Organic & $0.12^{* *}$ & 0.07 & +18.13 \\
Packaging material & & & -33.63 \\
Glass & $0.20^{* * *}$ & 0.09 & \\
Plastic & $-0.41^{* * *}$ & 0.07 & \\
& & &
\end{tabular}

Note: NS indicates the values are not statistically significant.

tion on the label had a significant effect on EVOO prices. In particular, the presence of the olive variety received a premium price of $+9.42 \%$ and the origin of production received a premium price of $+8.31 \%$ with respect to EVOOs without these indications. Organic certification was another important quality cue affecting EVOO prices. Organic oils had a premium price of $+12.75 \%$ compared to conventional products. Unexpectedly, the PDO certification did not affect the EVOO market prices. In terms of packaging material, the EVOO prices were positively affected by the glass container type $(+18.13)$ compared to the negative valuation of the plastic container $(-33.63)$.

\subsection{Consumer utility and WTP estimations}

The experiment was conducted during February 2015 in Zaragoza, Spain - a location widely used by food marketers and consulting companies since the socio-demographics are representative of the Spanish population census (see Appendix A, Table A1). The sample of participants was randomly selected based on gender, age, and education. Table 8 shows the characteristics of the final sample of respondents. Most respondents were female (68\%), which is expected since women in Spain still primarily take care of the household food shopping, and the target population was the primary food purchasers. Concerning age and education, it is observed that our sample is similar to the population, with approximately $25 \%$ of respondents aged between 35 and 44 years, and over $40 \%$ aged over 55 years. Around $50 \%$ of the sample had secondary education.

Results from the EC-RPL with correlated errors are presented in Table 9. All estimations were conducted using NLogit 5.0 (Econometric Software, Inc. - USA and Australia). Assuming homogenous preferences, we first estimated an MNL model. To relax this assumption and allow heterogeneous preferences across individuals, an RPL was estimated, which takes into account that each individual made four choices (Train, 2003). Given that the design alternatives might have a higher utility variance compared with the no-buy alternative, we estimated an EC-RPL. Finally, assuming that taste parameters could be correlated, we estimated an EC-RPL with correlated errors. Comparing the results of the four models, the EC-RPL with correlated errors at-

6 The following formula was applied: $\%$ change $=\{\exp ($ coefficient $)-1\}$. 
Table 8

Descriptive analysis of the sample and socio-demographic characteristics.

\begin{tabular}{lll}
\hline & & $\begin{array}{l}\text { Population } \\
\text { Spain }\end{array}$ \\
\hline Sample size & Sample & - \\
Gender & 216 & \\
Male & $31.75 \%$ & $50.90 \%$ \\
Female & $68.25 \%$ & $49.10 \%$ \\
Age (years) & & \\
Age of responders (average, standard & 47.26 & 42.90 \\
deviation) & $(16.22)$ & \\
18-34 & $23.08 \%$ & $24.12 \%$ \\
$35-44$ & $18.08 \%$ & $20.62 \%$ \\
$45-54$ & $19.07 \%$ & $18.56 \%$ \\
$>$ 55 & $37.06 \%$ & $36.70 \%$ \\
Education level b & & \\
Primary education & $18.35 \%$ & $24.88 \%$ \\
Secondary education & $44.50 \%$ & $47.64 \%$ \\
University education & $37.16 \%$ & $27.48 \%$ \\
\hline
\end{tabular}

Note: ${ }^{a}$ Provisional data obtained from the Spanish Statistical Institute (INE) register, 1 January 2015 (www.ine.es). ${ }^{b}$ (OECD - Organization for Economic Cooperation and Development, 2014).

tained the best fit $^{7}$ according to the log-likelihood, the pseudo- $\mathrm{R}^{2}$ and the Akaike Information Criterion (AIC). Hence, we will only discuss the estimates of the EC-RPL with the correlated error model below. For the model estimations, we used Halton draws rather than pseudo-random draws, since Halton draws provides more accurate simulations (Train, 2003).

As expected, the $\alpha$ is negative and statistically significant, indicating that consumers gain a lower utility from choosing any alternative than the no-buy option. ${ }^{8}$ The results from the EC-RPL with correlated errors model indicated that the price coefficient was negative and statistically significant in accordance with economic theory. Participant utility increased when an EVOO carried the PDO quality certification in comparison to one that did not. In terms of origin of production, a higher utility was obtained when the EVOO was produced in the county and the region in comparison to an EVOO from the rest of Spain.

The standard deviations for the three dummy variables (county, region, and PDO) were statistically significant, indicating unobserved heterogeneity in taste preferences across participants. Moreover, the hypothesis of correlation across utility is corroborated, since the error component for the alternative specific constant (sigma) is statistically significant.

Finally, the results from the marginal WTP estimates indicated that, on average, consumers were willing to pay an additional price premium of $2.13 € / \mathrm{L}$ for an EVOO that carried the PDO certification compared to one without this indication. In the same way, participants were willing to pay an additional premium of $1.51 € / \mathrm{L}$ for an EVOO that was produced in the county, and $1.27 € / \mathrm{L}$ for an EVOO produced in the region relative to an EVOO from the rest of Spain.

\section{Discussion}

This study combined an HP approach with an RCE to examine whether there is a relationship between the value of quality attributes in the market place based on price derived from a hedonic price approach, and the value of the attributes based on consumer utility derived from a real choice experiment.

\footnotetext{
7 Available from the authors upon request.

8 The percentage of participants who chose the no-buy option is small and lies between $18.06 \%$ for the first choice task, $30.56 \%$ for the second choice task, $32.41 \%$ for the third choice task, and $21.76 \%$ for the fourth choice task.
}

The results from the HP approach suggested that EVOO prices were positively affected by leading brands mostly purchased at hypermarkets in comparison to private store brands purchased at most neighborhood and discount stores. This is an expected result since the brand variability in hypermarkets is higher than in neighborhood and discount stores. In particular, while in hypermarkets the presence of private store brands did not exceed $34.1 \%$, the percentage of private brands in neighborhood and discount stores rose to $56.6 \%$ in 2017 (San Esteban, 2017). The association that may cause consumers to react skeptically to private store brands in some categories might be related to the association between their lower cost/lower quality positioning with respect to other products (Del Vecchio, 2001; Karipidis et al., 2005). The positive premium that the indication of olive variety had on price provides evidence that the EVOO sector has indeed increased in differentiation. Consumers' knowledge has also increased, because depending on the olive variety (Arbequina, Picual, Hojiblanca) consumers can form expectations regarding the taste of the EVOO (i.e., fruity, pungent, etc.). This result is in line with Cabrera et al. (2015) who illustrated the importance given to the olive variety in Spain. In terms of container materials, results show that a plastic container was valued negatively in comparison to a glass container, which received a premium price. Overall, a plastic container is associated with a lower quality product when compared to a glass container, especially for olive oil (Cabrera et al., 2015; Rosa et al., 2013).

Although there were relatively few organic olive oils in the Spanish market, results showed that this certification was an important quality cue that positively affected EVOO market prices. This result is in contrast with Torres-Ruiz et al. (2018) and Yangui et al. (2016) who reported consumer disutility for organic certification, and in line with other previous researchers who have suggested that organic certification adds value to olive oils (Bernabéu and Díaz, 2016; Boncinelli et al., 2016; Cacchiarelli et al., 2016; Cavallo et al., 2018; Cavallo and Piqueras-Fiszman, 2016; Del Giudice et al., 2015; Liberatore et al., 2017; Roselli et al., 2016, 2018; Vlontzos and Duquenne, 2014). Unexpectedly, the European PDO quality certification did not affect the market prices of EVOOs in Spain. This result is in line with previous research by Carbone et al. (2018) in Italy who found negative effects on price for olive oils with PDO, and Cabrera et al., 2015 in Spain who found no influence on price for EVOOs with PDO. Contrary to the PDO quality certification, the presence of production origin on the label had a positive influence on EVOO prices. As extensively shown by other authors, the origin of production is one of the most important aspects for many consumers of EVOOs (Ballco et al., 2015; Cabrera et al., 2015; Fotopoulos and Krystallis, 2001; Jiménez-Guerrero et al., 2012; Romo-Muñoz et al., 2017; Sottomayor et al., 2010; Yangui et al., 2014).

In terms of consumer utilities, participants obtained the highest utility from the PDO quality certification followed by the county and regional origin of production, in comparison to an EVOO coming from the rest of Spain. These results appear to be consistent with the previous literature that explored consumer utility for olive oils and found high utilities for the PDO quality certification (Ballco et al., 2015; Boncinelli et al., 2016; Panico et al., 2014; Yangui et al., 2016), and the origin of production (Ballco et al., 2015; Romo-Muñoz et al., 2017; Yangui et al., 2014).

In terms of whether there is a relationship between the premium prices derived from the HP model and the utility/willingness to pay estimates from the RCE for the common attributes (H1), we show that one of the attributes (i.e., origin of production) received premium prices and positive utilities by consumers, while the other one (i.e., PDO certification) affected only utilities, but not the EVOO prices on the market. In other words, consumers were willing to pay an additional price premium for PDO certification but the market prices for EVOO with and without PDO certification were not significantly differ- 
Table 9

Results from the random parameter logit with correlated errors (EC-RPL).

\begin{tabular}{|c|c|c|c|c|c|c|}
\hline \multirow[t]{2}{*}{ Attributes } & \multicolumn{2}{|c|}{ Random parameters in utility function } & \multicolumn{2}{|c|}{ Standard deviation of parameters distribution } & \multicolumn{2}{|l|}{ WTP (€/litter) } \\
\hline & Mean estimation & Z-ratio & Coefficient & Z-ratio & Mean estimation & Z-ratio \\
\hline Constant $(\alpha)$ & $3.67^{* * *}$ & 8.70 & - & - & - & - \\
\hline Price & $-0.89 * * *$ & -12.92 & - & - & - & - \\
\hline County & $1.34 * * *$ & 5.33 & $0.81 * * *$ & 2.12 & $1.51^{* * *}$ & 4.06 \\
\hline Region & $1.13^{* * *}$ & 4.48 & $0.98^{*}$ & 1.56 & $1.27^{* * *}$ & 4.35 \\
\hline $\mathrm{PDO}^{\mathrm{a}}$ & $1.90 * * *$ & 8.77 & $1.27^{* *}$ & 2.19 & $2.13^{* * *}$ & 7.13 \\
\hline Sigma & $2.04 * * *$ & 7.49 & - & - & - & - \\
\hline \multicolumn{7}{|l|}{ Summary Statistics } \\
\hline N. of observations & 864 & & & & & \\
\hline $\mathrm{N}$. of parameters & 12 & & & & & \\
\hline Log likelihood & -648.23 & & & & & \\
\hline Pseudo- $\mathrm{R}^{2}$ & 0.32 & & & & & \\
\hline AIC & 1320.50 & & & & & \\
\hline $\mathrm{AIC} / \mathrm{N}$ & 1.53 & & & & & \\
\hline
\end{tabular}

Note: $* * * * *$, and $*$ denote significance at the $1 \%, 5 \%$, and $10 \%$ levels, respectively.

ent. One reason for this mismatch is explained by Levitt (1960) in his ground-breaking article "Marketing Myopia" where he argued that firms tend to have a narrow view of themselves, the market, and their role in the market. Firms acknowledge the existence of the consumer environment and preferences; however, they do not pay it the attention it deserves. As a result, they fail to capture shifts in consumer values and lifestyles. Based on Levitt's analysis, the food industry struggle to fulfill consumer expectations may come in part from a lack of insight into temporal shifts in consumers' everyday lives (Levitt, 1960; Wikström et al., 2016). These changes are also reflected in the olive oil empirical evidence of Carbone et al. (2018) in Italy, Sayadi et al. (2016) in Spain, and Vlotzos and Duquenne (2014) in Greece, who demonstrated new trends in consumption and purchasing decision criteria, such as local and typical attributes, and environmental as well as ethical issues.

Hence, while we maintain that PDO certification is an important attribute that helps consumers differentiate the quality of an EVOO, at a regional level where the local producers are well known, this attribute does not add any value to the prices of EVOOs in the market. This result is in line with Cabrera et al. (2015) for EVOO in Spain, who showed that the local origin of production label had positive effects on prices in comparison to PDO certification which did not affect the price. In addition, this result was also highlighted by Marcoz et al. (2016), who suggested that PDO quality certification has higher value the further the consumer is from the area of production.

\section{Conclusions and limitations}

Overall, the results did not find a direct relationship for the two common attributes (the origin of production and the European quality certification PDO) between the premium prices derived from an HP market valuation and the utilities derived from an RCE. However, the presence of production origin on the label positively influenced EVOO prices and, in the same way, consumers were willing to pay a price premium for local origins. On the other hand, this relationship was not found for PDO certification, because although consumers were willing to pay a price premium for the PDO EVOO, the presence of a PDO on the bottle sold on the market did not influence EVOO prices. Consumer behavior for a typical product, such as an EVOO that is consumed on a regular basis, appears to be stable but, in reality, faces constant changes in differentiation. The most influential attributes in terms of utility and WTP estimates found were the origin of production (i.e., county and region) for EVOOs, and PDO quality certification. In the market, the attributes that influenced EVOO prices were labels that in- dicate the olive variety, organic certification, origin of production, sold in glass containers and in establishments with a high variety of leading brands.

A limitation of this research is that the sample used was based on products available at the main supermarket chains where consumers habitually purchase their entire food basket, but it did not take into account specialized establishments such as delicatessens and gourmet shops. For this reason, in addition to the selected price range, other interesting attributes such as nutritional and health claims, and additional EVOOs with organic and other PDO labels, might have been neglected. Secondly, the geographical area in which the study was applied was restricted (Zaragoza - Aragon). It would be interesting to compare the results obtained in other areas of influence, and with other PDO virgin olive oils with similar characteristics. Finally, the HP approach assumes a state of perfect competition, when in reality there are a large number of small cooperatives competing with large private firms and distribution companies that may be acting as oligopolies.

Even with its limitations, this research presents several practical implications. The results of this study may be of use in the design of different strategies to boost demand according to the premium prices attached to the quality attributes of both methodologies. EVOO companies should be willing to differentiate their products taking into account those attributes that affect prices in the local market and also consider consumer utilities for the EVOOs sold outside the region and to international markets. Similarly, those producers who want to gain competitive advantages, should not be satisfied by just offering products to the market, but should strive to create value for each customer specifically. The more distinctive and inimitable a product is, the more likely the company is to gain loyal customers. Furthermore, consumer awareness about olive variety and clear identification of production origin should encourage producers to develop new products based on single olive varieties characterized by different sensory attributes.

\section{Declaration of competing interest}

None.

Appendix A.

\footnotetext{
${ }^{9}$ Around $80 \%$ of the total olive oil sold in the Spanish market is managed by only six companies that highlight the symmetry of the market (Cabrera et al., 2015; MAPA Ministry of Agriculture, Fisheries and Food, 2003).
} 
Table A1

Population by sex and age in Spain and town

\begin{tabular}{|c|c|c|c|c|c|c|}
\hline \multirow[t]{2}{*}{ Total } & \multicolumn{3}{|c|}{ Gender ${ }^{a}$} & \multicolumn{3}{|l|}{$\operatorname{Age}^{\mathrm{a}}$} \\
\hline & & Female & Male & $18-34$ & $35-44$ & $45-54$ \\
\hline Spain & $46,624,382$ & 50.90 & 49.10 & 24.12 & 20.62 & 18.5 \\
\hline Town & 956,006 & 50.90 & 49.10 & 22.34 & 20.13 & 18.2 \\
\hline
\end{tabular}

Source: Spanish Census of Population, 2015) www.ine.es. ${ }^{a}$ Expressed in percentages.

\section{Funding}

This work was supported by the "Plan de Investigación del Fondo de Inversiones de Teruel (Plan FITE)"; Project entitled: "Cadena de producción, potential de mercado y externalidades territoriales en la Denominación de Origen Aceite del Bajo Aragón" (454-A), Zaragoza, Spain.

\section{Uncited reference}

\section{References}

Alfnes, F., Guttormsen, A.G., Steine, G., Kolstad, K., 2006. Consumers' willingness to pay for the color of salmon: A choice experiment with real economic incentives. Am. J. Agric. Econ. 88 (4), 1050-1061.

Angulo, A., Gil, J.M., Gracia, A., Sánchez, M., 2000. Hedonic prices for Spanish red quality wine. Br. Food J. 102 (7), 481-493.

Ballco, P., de-Magistris, T., 2018. Valuation of nutritional and health claims for yoghurts in Spain: A hedonic price approach. Span. J. Agric. Res. 16 (2), 108. doi:10.5424/sjar/ 2018162-12130.

Ballco, P., Gracia, A., Jurado, J., 2015. Consumer Preferences for Extra Virgin Olive Oil with Protected Designation of Origin (PDO). pp. 607-612. Retrieved from. http://hdl. handle.net/10532/3043.

Bazzani, C., Caputo, V., Nayga, R.M., Canavari, M., 2017. Revisiting consumers' valuation for local versus organic food using a non-hypothetical choice experiment: Does personality matter? Food Qual. Prefer. 62, 144-154. doi:10.1016/j.foodqual.2017.06.019.

Bernabéu, R., Díaz, M., 2016. Preference for olive oil consumption in the Spanish local market. Span. J. Agric. Res. 14 (4), 0108.

Boncinelli, F., Contini, C., Romano, C., Scozzafava, G., Casini, L., 2016. Territory, environment, and healthiness in traditional food choices: insights into consumer heterogeneity. Int. Food Agribus. Manag. Rev. 20 (1), 143-157. doi:10.22434/IFAMR2015.0177.

Box, G.E.P., Cox, D.R., 1964. An analysis of transformations. J Roy Stat Soc B 26, 211-252.

Cavallo, C., Piqueras-Fiszman, B., 2016. Visual elements of packaging shaping healthiness evaluations of consumers: The case of olive oil. J. Sens. Stud. 32 (1), e12246. doi:10.1111/joss.12246.

Cabrera, E.R., Arriaza, M., Rodríguez-Entrena, M., 2015. Is the extra virgin olive oil market facing a process of differentiation? A hedonic approach to disentangle the effect of quality attributes. Grasas Aceites 66 (4), 105. doi:10.3989/gya.0253151.

Cacchiarelli, L., Carbone, A., Laureti, T., Sorrentino, A., 2016. The value of the certifications of origin: a comparison between the Italian olive oil and wine markets. Br. Food J. 118 (4), 824-839. doi:10.1108/BFJ-05-2015-0180.
Campbell, D., 2007. Willingness to Pay for rural landscape improvements: combining mixed logit and random-Effects models. J. Agric. Econ. 58 (3), 467-483. doi:10.1111/ j.1477-9552.2007.00117.x.

Carbone, A., Cacchiarelli, L., Sabbatini, V., 2018. Exploring quality and its value in the Italian olive oil market: a panel data analysis. Agricultural and Food Economics 6 (1), 6. doi:10.1186/s40100-018-0102-8.

Carpenter, J.P., Harrison, G.W., 2004. In: Field Experiments in Economics, 10. Emerald (MCB UP), Bingley.

Cavallo, C., Caracciolo, F., Cicia, G., Del Giudice, T., 2018. Extra-virgin olive oil: are consumers provided with the sensory quality they want? A hedonic price model with sensory attributes. J. Sci. Food Agric. 98 (4), 1591-1598. doi:10.1002/jsfa.8633.

Chang, J.B., Lusk, J.L., Norwood, F.B., 2009. How closely do hypothetical surveys and laboratory experiments predict field behavior? Am. J. Agric. Econ. 91 (2), 518-534. doi:10.1111/j.1467-8276.2008.01242.x.

Clodoveo, M.L., Camposeo, S., Gennaro, B.D., Pascuzzi, S., Roselli, L., 2014. In the ancient world, virgin olive oil was called "liquid gold" by Homer and "the great healer" by Hippocrates. Why has this mythic image been forgotten? Food Res. Int. 62, 1062-1068. doi:10.1016/j.foodres.2014.05.034

Costanigro, M., McCluskey, J.J., Mittelhammer, R.C., 2007. Segmenting the wine market based on Price: Hedonic regression when different Prices mean different Products. J. Agric. Econ. 58 (3), 454-466. doi:10.1111/j.1477-9552.2007.00118.x.

de-Magistris, T., Gracia, A., 2014. Do consumers care about organic and distance labels? An empirical analysis in Spain. Int. J. Consum. Stud. 38 (6), 660-669. doi:10.1111/ ijcs.12138.

Del Giudice, T., Cavallo, C., Caracciolo, F., Cicia, G., 2015. What attributes of extra virgin olive oil are really important for consumers: a meta-analysis of consumers' stated preferences. Agricultural and Food Economics 3 (1), 1-15.

Del Vecchio, D., 2001. Consumer perceptions of private label quality: the role of product category characteristics and consumer use of heuristics. J. Retail. Consum. Serv. 8 (5), 239-249. doi:10.1016/S0969-6989(00)00030-8.

Dios-Palomares, R., Martínez-Paz, J.M., 2011. Technical, quality and environmental efficiency of the olive oil industry. Food Policy 36 (4), 526-534. doi:10.1016/ j.foodpol.2011.04.001.

B. DuquesneS. MatendoP. LebaillyProfiling food consumption: comparison between USA and EURetrieved fromhttp://www.agriculture.wallonie.be/apps/spip_wolwin/ IMG/pdf/usa.pdf200611

Fotopoulos, C., Krystallis, A., 2001. Are quality labels a real marketing advantage? J. Int Food \& Agribus. Mark. 12 (1), 1-22. doi:10.1300/J047v12n01 01.

García-Galán, M. del M., Román Suero, B., Chamorro Mera, A., 2019. Imagen de España como productor de aceite de oliva: Un análisi entre importadores. Boletin Economico de ICE 47-58. doi:10.32796/bice.2019.3109.6779.

González, J., Melo, O., 2008. Uso de modelos hedónicos y de búsqueda para el análisis de precios de vinos en supermercados. Revista Economía Agraria 12, 1-14.

Gracia, A., Perez y Perez, L., 2004. Factores determinantes del precio de la carne de ternera: un analisis hedonico. Economía Agraria y Recursos Naturales 4 (8), 87-104.

Grebitus, C., Lusk, J.L., Nayga, R.M., 2013. Explaining differences in real and hypothetical experimental auctions and choice experiments with personality. J. Econ. Psychol. 36, $11-26$.

Hamukwala, P., Oparinde, A., Binswanger-Mkhize, H.P., Kirsten, J., 2019. Design factors influencing willingness-to-Pay Estimates in the becker-DeGroot-marschak (BDM) mechanism and the non-hypothetical choice Experiment: A case of biofortified maize in Zambia. J. Agric. Econ. 70 (1), 81-100. doi:10.1111/1477-9552.12273.

Hess, S., Rose, J.M., Bain, S., 2009. In: Random Scale Heterogeneity in Discrete Choice Models, 25. (Washington DC).

IOC - International Olive Council, 2019. Estadísticas de producción y exportación de aceite de oliva. Consejo Oleícola Internacional Recuperado de. http://www. internationaloliveoil.org. (accessed 15 May 2019).

Jiménez-Guerrero, J.F, Gázquez-Abad, J.C., Mondéjar-Jiménez, J.A, Huertas-García, R, 2012. Consumer preferences for olive-oil attributes: A review of the empirical literature using a conjoint approach. Olive Oil - Constituents, Quality, Health Properties and Bioconversions 1, 233-246. doi:10.5772/30390.

P. KaranikolasT.P. CorreiaV. Martinez-GomezF. GalliP.A. HernandezL. FastelliG. GoussiosFood system integration of olive oil producing small farms: a comparative study of four Mediterranean regionsRetrieved fromhttp://www.ifsa2018. gr/uploads/attachments/197/Theme5 Karanikolas.pdf201820

Karipidis, P., Tsakiridou, E., Tabakis, N., 2005. The Greek olive oil market structure. Agric Econ. Rev. 6 (1), 9

Lancaster, K.J., 1966. A new approach to consumer theory. J. Political Econ. 74 (2), $132-157$. 
Levitt, T., 1960. Marketing Myopia. Harvard Business Review, pp. 45-56. July-August.

Liberatore, L., Casolani, N., Murmura, F., 2017. Perception of extra-virgin olive oil certifications: A commodity market perspective. Izvestiya (1), 77-82.

Loomis, J., Bell, P., Cooney, H., Asmus, C., 2009. A comparison of actual and hypothetical willingness to pay of parents and non-parents for protecting infant health: The case of nitrates in drinking water. J. Agric. Appl. Econ. 41 (3), 697-712.

Loureiro, M.L., McCluskey, J.J., 2000. Assessing consumer response to protected geographical identification labelling. Agribussiness 16 (3), 309-320.

Lusk, J.L., Schroeder, T.E.D.C., 2004. Are choice experiments incentive compatible? A test with quality differentiated beef steaks. Am. J. Agric. Econ. 86 (2), 467-482.

MAPA - Ministry of AgricultureFisheries and foodEstudios de Comercialización. Multisectorial [Gov]. Retrieved April 9, 2019, from Diagnosis and strategic analysis of the Spanish agribusiness sector. Year 2003 website:https://www.mapa.gob.es/ es/alimentacion/temas/consumo-y-comercializacion-y-distribucion-alimentaria/ estudios-de-comercializacion/varios-sectores/diagnostico.aspx2003

Marcoz, E.M., Melewar, T.C., Dennis, C., 2016. The value of region of origin, producer and protected designation of origin label for visitors and locals: The case of Fontina cheese in Italy. Int. J. Tour. Res. 18 (3), 236-250. doi:10.1002/jtr.2000.

Mcfadden, D., 1974. Conditional logit analysis of qualitative choice behavior. In: Frontiers in Econometric. Academic Press, New York, p. 252.

MECS - Ministry of EducationCulture and SportsThe olive grove landscapes of AndalusiaRetrieved December 23, 2018, from UNESCO World Heritage Centre website:https: //whc.unesco.org/en/tentativelists/6169/2017

L. MontesLos 5 supermercados online que más cuota de mercado tienen en EspañaRetrieved April 1, 2019, from Business Insider websitehttps://www.businessinsider.es/ 5-supermercados-online-que-mas-cuota-mercado-tienen-espana-3042872018

L. MontesEl ránking de los supermercados con más cuota de mercado en España: mercadona está cada vez más lejos del restoRetrieved April 1, 2019, from Business Insider websitehttps://www.businessinsider.es/estos-son-supermercados-mas-cuotamercado-espana-3073632019

Murphy, J.J., Allen, P.G., Stevens, T.H., Weatherhead, D., 2005. A meta-analysis of hypothetical bias in stated preference valuation. Environ. Resour. Econ. 30, 313-325. doi:10.1007/s10640-004-3332-z.

OECD - Organization for Economic Cooperation and DevelopmentCompare your country - Education at a glance2014http://www.oecd.org/education/Education-at-aGlance-2014.pdf2014Accessed May 21, 2018

Panico, T., Giudice, T.D., Caracciolo, F., 2014. Quality dimensions and consumer preferences: A choice experiment in the Italian extra-virgin olive oil market. Agric. Econ. Rev. 15 (2), 100-112.

Reboredo-Rodríguez, P., Varela-López, A., Forbes-Hernández, T.Y., Gasparrini, M., Afrin, S., Cianciosi, D., Giampieri, F., 2018. Phenolic compounds isolated from olive oil as nutraceutical tools for the prevention and management of cancer and cardiovascular diseases. Int. J. Mol. Sci. 19 (8), 2305. doi:10.3390/ijms19082305.

Romo-Muñoz, R.R., Moya, M.L., Gil, J.M., 2015. Market values for olive oil attributes in Chile: a hedonic price function. Br. Food J. 117 (1), 358-370. doi:10.1108/ BFJ-01-2014-0009.

Romo-Muñoz, R.A., Cabas-Monje, J.H., Garrido-Henrríquez, H.M., Gil, J.M., 2017. Heterogeneity and nonlinearity in consumers' preferences: An application to the olive oil shopping behavior in Chile. PLoS One 12 (9), e0184585. doi:10.1371/ journal.pone.0184585.

Rosa, M.P., Zamora, M.V., Ruiz, F.J.T., Armenteros, E.M.M., Salcedo, M.G., 2013. Posicionamiento de envases en el mercado del aceite de oliva virgen extra: un estudio exploratorio. ITEA, No 1, 107-123.

Roselli, L., Carlucci, D., Gennaro, B.C.D., 2016. What is the value of extrinsic olive oil cues in emerging markets? Empirical evidence from the U.S. E-Commerce retail market. Agribusiness 32 (3), 329-342. doi:10.1002/agr.21454.

Roselli, L., Carlucci, D., Rover, O.J., Gennaro, B.D., 2018. The effects of extrinsic cues on olive oil price in Brazil. J. Int. Food \& Agribus. Mark. 30 (1), 70-87. doi:10.1080/ 08974438.2017.1387883.

Rosen, S., 1974. Hedonic prices and implicit markets: Product differentiation in pure competition. J. Political Econ. 82 (1), 34-55.
Salas-Salvadó, J., Becerra-Tomás, N., García-Gavilán, J.F., Bulló, M., Barrubés, L., 2018. Mediterranean diet and cardiovascular disease prevention: What do we know? Prog. Cardiovasc. Dis. 61 (1), 62-67. doi:10.1016/j.pcad.2018.04.006.

N. San EstebanEstas son las marcas que sobreviven al imperio de Hacendado en MercadonaRetrieved April 5, 2019, from El Español website:https://www.elespanol.com/ economia/empresas/20170612/223228165_0.html2017

Sánchez, M., Angulo, A.M., Gracia, A., Gil, J.M., 2000. Hedonic prices for Spanish red quality wine. Br. Food J. 102 (7), 481-493. doi:10.1108/00070700010336445.

Sanjuán-López, A.I., Resano-Ezcaray, H., Camarena-Gómez, D.M., 2009. Developing mar keting strategies for Jiloca saffron: a price hedonic model. Span. J. Agric. Res. 7 (2), 305-314. doi:10.5424/sjar/2009072-421.

Sayadi, S., Erraach, Y., Parra-López, C., 2016. Translating consumer's olive-oil quality-attribute requirements into optimal olive-growing practices: A quality function deployment (QFD) approach. Br. Food J. 119 (1), 190-214. doi:10.1108/BFJ-05-2016-0228.

Scarpa, R., Del Giudice, T., 2004. Market segmentation via mixed logit: Extra-virgin olive oil in urban Italy. J. Agric. Food Ind. Organ. 2 (1), 1-20.

Scarpa, R., Campbell, D., Hutchinson, W.G., 2007. Benefit estimates for landscape improvements: sequential Bayesian design and respondents' rationality in a choice experiment. Land Econ. 83 (4), 617-634.

Scarpa, R., Thiene, M., Train, K., 2008. Utility in willingness to Pay space: A Tool to address confounding random scale Effects in destination choice to the alps. Am. J. Agric. Econ. 90 (4), 994-1010. doi:10.1111/j.1467-8276.2008.01155.x.

M. SottomayorD.M. Souza-MonteiroM.S. TeixeiraValuing nested names in the Portuguese olive oil market: An exploratory study (No. 95233)Retrieved from European Association of Agricultural Economists website:https://ideas.repec.org/p/ags/eaa116/ 95233.html2010

Storniolo, C.E., Casillas, R., Bulló, M., Castañer, O., Ros, E., Sáez, G.T., Moreno, J.J., 2017. A Mediterranean diet supplemented with extra virgin olive oil or nuts improves endothelial markers involved in blood pressure control in hypertensive women. Eur. J. Nutr. 56 (1), 89-97. doi:10.1007/s00394-015-1060-5.

Torres-Ruiz, F.J., Vega-Zamora, M., Parras-Rosa, M., 2018. False barriers in the purchase of organic foods. The case of extra virgin olive oil in Spain. Sustainability 10, 461. doi:10.3390/su10020461.

Train, K., 2003. Discrete choice methods with simulation. SUNY-OswegoDepartment of Economics 2 (2), 15-23. https://econpapers.repec.org/bookchap/oettbooks/emetr2. htm.

Vázquez-Araújo, L., Adhikari, K., Chambers, E., Chambers, D.H., Carbonell-Barrachina, A.A., 2014. Cross-cultural perception of six commercial olive oils: A study with Spanish and US consumers. Food Science and Technology International = Ciencia Y Tecnologia De Los Alimentos Internacional 21 (6), 454-466. doi:10.1177/ 1082013214543806 .

Vlontzos, G., Duquenne, M.N., 2014. Assess the impact of subjective norms of consumers' behaviour in the Greek olive oil market. J. Retail. Consum. Serv. 21 (2), 148-157. doi:10.1016/j.jretconser.2013.09.003.

Volinskiy, D., Adamowicz, W.L., Veeman, M., Srivastava, L., 2009. Does choice context affect the results from incentive-compatible experiments? The case of non-GM and country-of-origin premia in canola oil. Canadian J. Agric. Econ/Revue canadienne d'agroeconomie 57 (2), 205-221. doi:10.1111/j.1744-7976.2009.01148.x.

Vuong, Q.H., 1989. Likelihood ratio test for model selection and non-nested hypothesis. Econometrica 57, 307-333. doi:10.2307/1912557.

Wikström, S., Jönsson, H., Decosta, P.L., 2016. A clash of modernities: developing a new value-based framework to understand the mismatch between production and consumption. J. Consum. Cult. 16 (3), 824-851. doi:10.1177/1469540514528197.

Xiong, B., Sumner, D., Matthews, W., 2014. A new market for an old food: the U.S. demand for olive oil. Agric. Econ. 45 (S1), 107-118. doi:10.1111/agec.12133.

Yangui, A., Costa-Font, M., Gil, J.M., 2014. Revealing additional preference heterogeneity with an extended random parameter logit model: the case of extra virgin olive oil. Span. J. Agric. Res. 12 (3), 553-567. doi:10.5424/sjar/2014123-5501.

Yangui, A., Costa-Font, M., Gil, J.M., 2016. The effect of personality traits on consumers preferences for extra virgin olive oil. Food Qual. Prefer. 51, 27-38. doi:10.1016/ j.foodqual.2016.02.012.

Yue, C., Tong, C., 2009. Organic or local? Investigating consumer preference for fresh produce using a choice experiment with real economic incentives. Hortscience 44 (2), 366-371. 